\title{
Introducing blended learning: An experience of uncertainty for students in the United Arab Emirates
}

\author{
Linzi J. Kemp*
}

Department of Management and Public Administration, School of Business and Management, American University of Sharjah, Sharjah, UAE

(Received 1 April 2012; final version received 18 March 2013)

\begin{abstract}
The cultural dimension of Uncertainty Avoidance is analysed in this study of an introduction to blended learning for international students. Content analysis was conducted on the survey narratives collected from three cohorts of management undergraduates in the United Arab Emirates. Interpretation of certainty with blended learning was found in: student skills with technology; student acknowledgement of course organisation; and student appreciation of online feedback. Uncertainty with the introduction of blended learning was found: when membership was assigned for group work, higher quality research methods were introduced; where course structure lacked detail, increased time was required for new and different online activities. These international students, from countries with a high score on Uncertainty Avoidance, exhibited that dimension when introduced to blended learning. The implications of these findings are discussed, and strategies suggested for introducing blended learning to international students. The limitations of the study are considered, and a direction for future research is suggested. This is the first study on undergraduates in the Middle East for the effects of a cultural dimension when introducing blended learning. The findings increase the body of knowledge that relates to learning technology in the international business classroom.
\end{abstract}

Keywords: learning culture; blended learning pedagogy; differentiating cultures; learning design

\section{Introduction}

The pedagogical approach of study in this paper is that of blended learning, i.e. a mix of face-to-face and e-learning instruction (Deepwell and Malik 2008; Martins and Kellermann 2004). We study the effect of one dimension, from within a culture framework, on the introduction to blended learning for business undergraduates at a university in the United Arab Emirates (UAE).

In this study we consult two culture frameworks for the insight they can offer the educator (Hofstede 1980, 1983; Project GLOBE [Global Leadership and Organizational Effectiveness] 2010). The researchers in Project GLOBE consider that

People are not generally aware of the tremendous impact that national culture has on their vision and interpretation of the world. Because culture colors nearly every aspect of

*Corresponding author. Email: 1kemp@aus.edu 


\section{J. Kemp}

human behavior, a working knowledge of culture and its influences can be useful to executives operating in a multicultural business environment. (Javidan et al. 2006, p. 67)

We contend that educators may not be aware of the impact of culture, and that it is useful for an educator to recognise the influence of culture on their students. For culture will impact both the perception of the learning environment and learner's behaviour. Of course this is equally true of the educator's vision and interpretation, but that is for a separate study.

In the culture model, the UAE is classified within the Middle East cluster of nations, and we investigate Uncertainty Avoidance (UA) because of the high score in that region for this cultural dimension (House, Javidan, and Dorfman 2001; Javidan et al. 2006; Kabasakal and Bodur 2002). UA is defined as "the extent to which the members of a culture feel threatened by ambiguous or unknown situations" (Hofstede, Hofstede, and Minkov 2010, p. 191).

A confidential survey to evaluate the introduction of blended learning was administered to three cohorts of students. Content analysis of collected narrative data revealed student certainty and uncertainty for the introduction of a blended learning environment. Three indicators of certainty with a blended learning environment were found: student skills in the use of technology; student acknowledgement of course organisation; and student appreciation of online feedback. Uncertainty with the blended environment was also indicated: challenges with online research; learner seeking clarification about online tasks; uncertainty with material; and increased time on task.

Awareness about the cultural dimension of UA increased this educator's ability to diagnose potential challenges that may affect the introduction of blended learning (Bailey 2006; Sulkowski and Deakin 2010). Some lessons learned, and changes in pedagogy are suggested as a consequence of the study. The findings add to the body of knowledge, as this is the first study to be conducted on the effect of a cultural dimension for the introduction of blended learning to undergraduates in the UAE.

\section{Literature review}

\section{The context for the introduction of learning technology in the United Arab Emirates}

The UAE is a small country in the Middle East with a multi-cultural population of 8.26 million (UAE Statistics Bureau 2011). The introduction of learning technologies in western Higher Education is not a recent phenomenon, but for the UAE it is more recent, and is being pursued to support a knowledge economy (Alodiedat and Eyadat 2008; Mezias 2009; Owens and Price 2010).

The most important priority in UAE Higher Education is to change from traditional pedagogy, to prepare students for a technological workplace, with competency in "independent learning" and the "ability to work as a team" (UAE Minister of Higher Education and Scientific Research, His Highness Sheikh Nahayan Mubarak Al Nahayan, Mezies 2009, paragraphs 12-14). Academic study is required for the implications of learning technology, but research has, for the most part, been conducted outside the Middle East region (Alebaikan and Troudi 2011; Kemp 2011; Lansari, Tubaishat, and Al-Rawi 2010). Technological change in education and society has an implication for pedagogy because "optimal teaching and learning occur when teaching styles align with learning styles" (Proserpio and Gioia 2007, p. 69). 
It is therefore necessary to consider how technology may have affected learning styles for a generation of students.

Statistical data reveals that $75.9 \%$ of the UAE population use the Internet, and, as students in this study will have been brought up with such access, we can consider them to be the "Net Generation" or "the virtual-generation (V-Gen)" (Dobbins 2005; Internet World Stats 2010; Proserpio and Gioia 2007, p. 70). The Economist (Monitor 2010) recognises that for a generation who have grown up with the Internet, it may have "transformed their approach to education" (paragraph 1). The assumption is that this generation has expectations of using information technology in education, because of their lifetime experiences with computers (Dobbins 2005; Feiertag and Berge 2008). Blended learning combines the pedagogy of a traditional classroom with the use of technology (Motteram and Sharma 2009; Oblinger and Oblinger 2005). As such, blended learning is an environment deemed appropriate for so called "digital natives", brought up as they are on the use of computers, and confident with a variety of social media (Prensky 2001; Proserpio and Gioia 2007).

We educators must also be aware that, because of differing access and use amongst the same age group, "while technology is embedded in their lives, young people's use and skills are not uniform" (Bennett, Maton, and Kervin 2008, p. 783). Study of the cultural dimensions of these young people increases knowledge about their use and skill in the application of technology to learning (Postman 1992). Further academic study on the cultural dimensions of learners is also important because of increased diversity in face-to-face, blended and online classrooms worldwide (Kabasakal and Dastmalchian 2001).

\section{The dimension of $U A$ for the introduction of learning technology}

Two culture frameworks are of interest in this study because of the similarities in the findings for the Middle East (Hofstede 1980, 1983; Hofstede, Hofstede, and Minkov 2010; Javidan and House 2002; Project GLOBE 2010). For a discussion of the differences between the frameworks, see Hofstede 2006; Venaik and Brewer 2010.

The Middle East cluster of nations has a high score for the cultural dimension of UA (House et al. 2001; Ronen and Shenkar 1985; The Hofstede Centre 2012). UA, as previously defined, is "the extent to which the members of a culture feel threatened by ambiguous or unknown situations" [italics in the original] (Hofstede, Hofstede, and Minkov 2010, p. 195). Students in this research are studying in the UAE, and the majority of them are from the Middle East (University of X, Spring 2010). For these cultures, according to the Uncertainty Avoidance Index (UAI), there is "a high preference for avoiding uncertainty" (The Hofstede Centre 2012, UA, paragraph 2).

Various researchers have cited differences in learner expectations as being a culturally bound phenomenon, see, for instance, passivity in the learning of Asian students (Maxwell et al. 2000), and differences between European and Asian students' motivation to study (Selvarajah 2006). A study on Arab education (World Bank 2008) found that learners are passive recipients of knowledge and lack applied learning in "the higher-order cognitive skills such as flexibility, problem solving and judgment" (p. 89). Due to their schooling in the Arab region, students "have learned to completely depend on their teachers for acquiring knowledge" (Lansari, Tubaishat, and Al-Rawi 2010, p. 74). 


\section{J. Kemp}

Therefore, for Arab students, there could be a problem with adaptation to a blended learning environment because the learner "has to take the initiative and responsibility for what they select, manage and access in a limited time outside formal contact hours" (Deepwell and Malik 2008, p. 6). The introduction of blended learning at universities in the Kingdom of Saudi Arabia (KSA) faced the challenge of culture, related to low levels of student discipline and responsiveness because of traditional teaching methods (Alebaikan and Troudi 2011). Students high in UA indicate a preference for structured learning, have a concern for the right answers, hold an expectation that the educator has the correct answers, and attribute results to circumstances rather than acknowledging self-control for their learning (Sulimma 2005).

With students high in UA there may be an issue with blended learning because it depends on the learners being self-directed to complete activities, such as "peer discussion and collaboration, accessing library resources, reading, research and development and working through tutorial materials and workbooks" (Deepwell and Malik 2008, p. 5). It was found that in the KSA, students did lack sufficient selfdiscipline to succeed with online learning (Alebaikan and Troudi 2011). Blended learning is said to lead to shorter "seat-time" (Benson, Anderson, and Ooms 2011, p. 144), but that it relies on students, as self-directed learners, spending time on tasks outside the classroom environment. Lansari, Tubaishat, and Al-Rawi (2010) used a blended approach to extend independent learning skills for students in the UAE, finding that although it "allowed them to become independent learners, they still needed the guidance of instructors" (p. 73).

Learner perceptions, expectations and preferences are dependent on their culture; from more active to passive; more or less responsibility for learning; more or less interaction expected with peers and instructor (Rodrigues 2005; Sulkowski and Deakin 2010). Results from Rodrigues (2005), however, did not show strong differences between learners from high or low UA cultures, and the conclusion in that research was that cultural dimensions are only a starting point for investigation. Against this background, UA is a cultural dimension to consider within the student learning experience. The literature review leads to the research question: What evidence is there of learner uncertainty or certainty for the introduction of blended learning?

\section{Research methodology}

The methodology is a mixed model, following Miles and Huberman (2002), that "quantitative and qualitative inquiry can support and inform each other" (p. 396). Similarly to Geçer and Dag (2012), in their study of a blended learning experience, we invoked qualitative methodology. There is also an element of a mixed methods approach in this research, as quantitative analysis of data is represented.

\section{Sample}

The sample of international students comprises of undergraduates at a university in the UAE that follows an American curriculum, taught by a multicultural faculty experienced in American education. A total of 80 different nationalities study at the university, ten of those nationalities account for $78 \%$ of the student population, of which the majority are from the Middle East (University of X, Spring 2010). Although the individual nationalities in this sample remain unknown, due 
to survey confidentiality, they are from different cultures and are being taught in a country that is acknowledged as high in UA. This study is made up of three sections of junior level business undergraduates enrolled in an elective course on leadership. A total of 40/62 students $(65 \%)$ completed a survey during Fall and Spring semesters, 2009-2010, about their experiences following the introduction of blended learning.

\section{Data collection}

In support of a blended learning classroom, this author used a learning management system (LMS), ilearn, a customised version of Blackboard, that is also adopted in other UAE universities (Kemp 2010, 2011; Lansari, Tubaishat, and Al-Rawi 2010; Taha 2007). A survey was created and made available in the LMS. The number of questions was kept to four, deliberately few so as to encourage participants to answer. The survey elicited student narrative about their course experience through questions about: (1) what they loved, (2) what they found to be a challenge, (3) what they loathed, and (4) what was comforting to them (LCLC). The questions were "open" to encourage narrative comment about issues that participants considered important. The completion of the LCLC was voluntary, was not a graded component of the course, nor was there an incentive for its completion. Confidentiality was assured and maintained for the learners through the LMS tools that did not reveal student names. Participants remained unaware that the issues of learning technology or blended learning were of interest, instead the nature of the LCLC was explained to them as a survey to improve their learning environment. The survey was administered at mid-semester for two reasons: (1) to avoid a clash with the end of semester course evaluation and (2) to enable the Professor to make changes to the learning environment based on students' learning experience.

\section{Data analysis}

The research question was addressed through content analysis following a threestaged process.

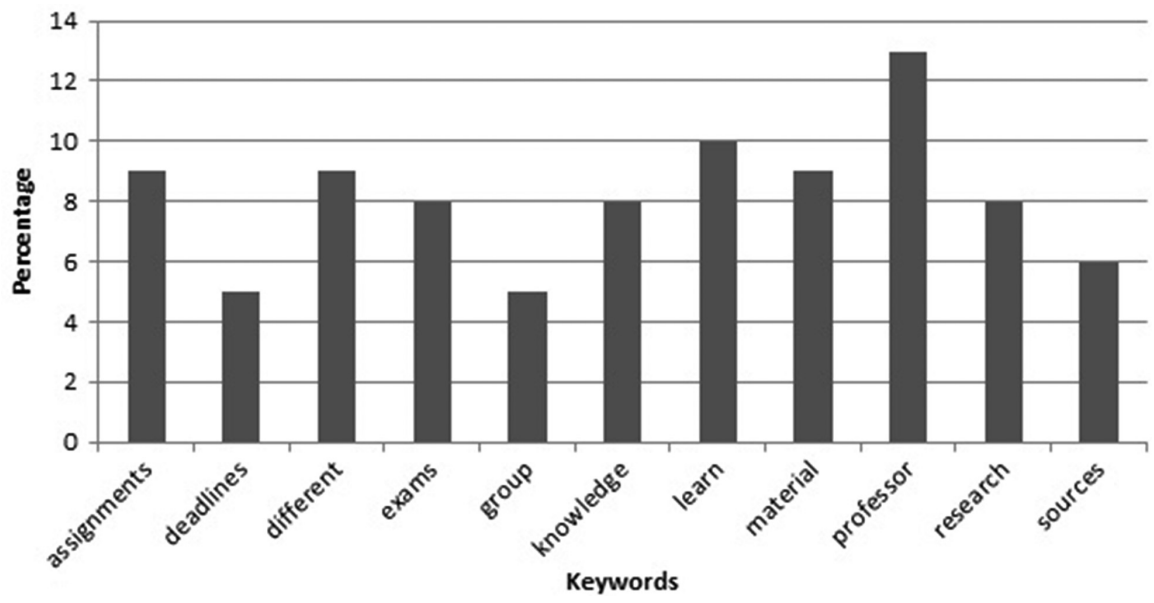

Figure 1. Stage 1: keywords. 


\section{J. Kemp}

Stage 1 was to code the narrative comments descriptively, i.e. without interpretation (Miles and Huberman 2004). This stage was achieved by conducting a word frequency query to reveal keywords that formed a lexicon of significance for the learners. This stage of the analysis involved the coding of many keywords of which, for reasons of brevity in this paper, the 11 most frequent are included. A quantitative analysis of the keywords is contained in Figure 1.

Figure 1 exhibits the comparative occurrence, by percentage, for each of the 11 most frequent words. For example, professor was cited 46 times, was the most cited word in the narratives and represents $13 \%$ of the top 11 .

Qualitative content analysis was conducted for stages 2 and 3 to more deeply interpret the student comments emanating from data.

Stage 2 of the analysis is where the comments were read and reread to interpret the backstage dynamics to the data from their context (Miles and Huberman 2004). At this stage, data was interpreted having become, "more knowledgeable about local dynamics, a more complex, more "backstage" web of motive turns up" (Miles and Huberman 2004, p. 57). The researcher reread all the comments and considered the context for the students, to classify data into positive and less positive comments (Geçer and Dag 2012). The answers to questions in the survey about love and comfort were considered as more likely to reveal certainty among students, i.e. contained positive comments relating to an aspect of the experience. Comments about challenge, and loathe, were considered together as potentially more likely to reveal uncertainty, i.e. were coded as less positive comments.

Stage 3 was enacted as a deeper interpretation of the content by recognising emergent patterns or themes of UA (Miles and Huberman 2004). To enhance the interpretation of the data, the narratives within all parts of the survey (LCLC) were read again to capture shared messages. Emergent themes were interpreted from the shared messages amongst student data relating to certainty or uncertainty with blended learning. Student quotations, extracted from data, illustrate the emergent themes.

\section{Findings}

The findings from the content analysis are now explained in relation to stages 1-3 making reference to the illustrative quotations extracted from the data. In Table 1, we represent the findings in alphabetical order to avoid a hierarchy of importance being attached to the elements of the blended learning experience.

Themes emerged as we interpreted what students were saying about their experience of blended learning. The story is one of appreciation for new experiences, but these are changes to traditional teaching, which take time to be accepted.

There was appreciation for the organisation of assignment deadlines available to students in the LMS (quotation 1). However, data about assignments revealed increased time on task due to searching for quality sources in the virtual library (quotations 2 and 16). Comments about time on task were found in the context of "deadlines", appearing at twice the rate in the uncertainty than the certainty classification. The course text and other materials are common to an American business curriculum, but lacked regional relevance (quotation 12). The introduction of local case studies posted in the LMS to ameliorate this was positively commented upon (quotation 11). Keywords, "knowledge" and "learn", repeated narration about increased time spent on knowledge acquisition. Keywords "research" and "sources" 
Table 1. Stages 1-3. Findings.

\begin{tabular}{|c|c|c|c|c|}
\hline $\begin{array}{l}\text { Stage } 1 . \\
\text { Keywords }\end{array}$ & & $\begin{array}{l}\text { Stage } 2 \text { context } \\
\text { Classifications }\end{array}$ & Stage 3 Themes & Uncertainty Avoidance \\
\hline $\begin{array}{l}\text { Descriptive } \\
\text { codes }\end{array}$ & Positive & Less positive & Emergent & $\begin{array}{l}\text { Implications for } \\
\text { pedagogy }\end{array}$ \\
\hline $\begin{array}{l}\text { Assignment } \\
\text { Deadlines }\end{array}$ & $\begin{array}{l}\text { 1. We know all our assignments and } \\
\text { their contents prior to the deadline. }\end{array}$ & $\begin{array}{l}\text { 2. The assignments are very demanding and requires a } \\
\text { lot of time and effort. }\end{array}$ & $\begin{array}{l}\text { Requires and trusts } \\
\text { teacher feedback }\end{array}$ & $\begin{array}{l}\text { LMS tools for feedback, } \\
\text { collection of materials, } \\
\text { gradebook, formative } \\
\text { feedback. }\end{array}$ \\
\hline Different & $\begin{array}{l}\text { 3. What makes it different is the } \\
\text { constant interaction in class. }\end{array}$ & $\begin{array}{l}\text { 4. The tasks that we need to perform are new } \\
\text { to me. }\end{array}$ & $>$ Interaction is beneficial & $\begin{array}{l}\text { Gradual introduction } \\
\text { of online team member } \\
\text { assignment. Instructor } \\
\text { as facilitator. }\end{array}$ \\
\hline Exams & $\begin{array}{l}\text { 5. We know whats going to be on the } \\
\text { exam. }\end{array}$ & $\begin{array}{l}\text { 6. I do not like that everyone has different questions in } \\
\text { the exam yet everyone had the same time allocation }\end{array}$ & $\begin{array}{l}>\text { Uncertainty with change } \\
\text { concept of unfairness. }\end{array}$ & $\begin{array}{l}\text { Explanation of tasks in } \\
\text { detail. }\end{array}$ \\
\hline Group & $\begin{array}{l}\text { 7. The practical group work where we } \\
\text { learn by practicing and } \\
\text { applying. }\end{array}$ & $\begin{array}{l}\text { 8. Not being able to choose the people to work with in } \\
\text { groups, since we sometimes have a good under- } \\
\text { standing of some classmates. }\end{array}$ & $\begin{array}{l}\text { Uncertainty with the } \\
\text { unknown/ unfamiliar } \\
\text { classmates }\end{array}$ & $\begin{array}{l}\text { Progressive change in } \\
\text { activities, towards blended. }\end{array}$ \\
\hline $\begin{array}{l}\text { Knowledge } \\
\text { Learn }\end{array}$ & $\begin{array}{l}\text { 9. Each class I feel that I learn more } \\
\text { concepts and discover new ways to } \\
\text { improve and develop my knowledge } \\
\text { and skills. }\end{array}$ & $\begin{array}{l}\text { 10. A challenge because of the need to cite sources } \\
\text { outside the textbook, specially the fact that } \\
\text { I do not learn names easily. }\end{array}$ & $\begin{array}{l}\text { Misconceptions about } \\
\text { activities - external forces. }\end{array}$ & $\begin{array}{l}\text { Introduction of skills } \\
\text { workshops }\end{array}$ \\
\hline Material & $\begin{array}{l}\text { 11. I love that we are able that we are } \\
\text { able to choose our own leaders for } \\
\text { the case study. }\end{array}$ & $\begin{array}{l}\text { 12. The scope of the textbook's discussion is extremely } \\
\text { narrow, dealing exclusively with issues from North } \\
\text { America. }\end{array}$ & $>$ Local/global sources & $\begin{array}{l}\text { Online assignments/ } \\
\text { resources/materials of } \\
\text { local relevance. }\end{array}$ \\
\hline Professor & $\begin{array}{l}\text { 13. Professor uses I-Learn frequently to } \\
\text { either guide us for assignments, or } \\
\text { to show us what is our stand in the } \\
\text { course-in terms of the grades. }\end{array}$ & $\begin{array}{l}\text { 14. Flexible with us, for example, with the } \\
\text { recording of interviews. }\end{array}$ & $\begin{array}{l}\text { Preference for rules } \\
\text { (security) expect } \\
\text { flexibility in the } \\
\text { application }\end{array}$ & $\begin{array}{l}\text { Flexibility in criteria for } \\
\text { assignments. }\end{array}$ \\
\hline $\begin{array}{l}\text { Research } \\
\text { Sources }\end{array}$ & $\begin{array}{l}\text { 15. Doing research to support our } \\
\text { answers in the midterm and } \\
\text { in-class assignments. }\end{array}$ & $\begin{array}{l}\text { 16. Preparing sources before the exam is very time } \\
\text { consuming. }\end{array}$ & $\begin{array}{l}\text { Time needed for } \\
\text { acquisition of new } \\
\text { knowledge and skills }\end{array}$ & $\begin{array}{l}\text { More time for acceptance } \\
\text { of changes in activities, for } \\
\text { new processes. }\end{array}$ \\
\hline
\end{tabular}




\section{J. Kemp}

were associated with the less positive classification (quotations 16) because of time and difference to the norm of searching online.

Learners commented on interaction as "different" in a blended classroom to the previous experience of a more traditional class. In quotation 9, there is appreciation for the acquisition of new knowledge and skills in each class. However, the key word "difference" also revealed uncertainty with change associated with new tasks (quotation 4), especially where change related to traditions in exam format. An "open laptop" exam format with individual questions (quotation 6) introduced the potential risk of failure for students. Unless students considered they had received a lot of practice, e.g. in online exam preparation (quotation 5) or in searching for sources (quotation 15).

There were misconceptions also about unfamiliar activities, and a desire for more information expressed (quotation 10). Within this study of learners from a high UA culture, there was evidence of reliance on Professor feedback (quotation 13). The professor was also expected to be flexible in expectations for the use of technology. Quotation 14 relates to student use of competence with technology, but needing flexibility (reliant on teacher permission) in its use.

A learner revealed how knowledge was attained through online group work (quotation 7). The interpretation was that interaction is beneficial (quotation 3). Students appreciated group work, although there was a sense of uncertainty with unfamiliar classmates (quotation 8).

To follow is a discussion about the themes that arose as implications for teaching and learning when a blended environment is introduced to students with high UA.

\section{Discussion}

The emergent themes revealed implications for changes in pedagogy to avoid uncertainty when introducing students to blended learning. These implications are contained in the final column of Table 1 and are considered further in this discussion.

Our study findings did not reveal student certainty or uncertainty about the shift to a more technologically supported classroom, concurring with findings related to this generation's familiarity with technology. However, as Bennett, Maton, and Kervin (2008) argue, familiarity with technological tools is not the whole debate, surrounding the introduction of learning technology for the "Net Generation", of so called "digital natives" (p. 775). Our research firmly places culture into the debate about learning technology/blended learning. The cultural dimension of high UA requires the international educator to consider culture and adapt blended learning to avoid potential resistance by those who are risk averse to a new learning environment (Adeoye and Wentling 2007).

As there is a tendency for less structure in blended learning, those from cultures who prefer more structure may perceive the environment rather vague (Sulkowski and Deakin 2010). Uncertainty manifested itself through survey narrative in students' requests for more structured learning, e.g. explicit verbal and written direction was wanted. Learners from clusters that rate high on UA indicate a preference for structured learning and expect the professor to have the correct answers (Eom, Wen, and Ashill 2006; Sulimma 2005). 
The professor had made full use of the LMS (online calendar, e-mail responses and online gradebook). To structure the blended environment towards less ambiguity for students, there is an opportunity to post asynchronous "diagnostic feedback", on why answers are wrong, and "prescriptive feedback", on how the answers could be improved for next time (Eom, Wen, and Ashill 2006, p. 220). Although an educator risks student uncertainty, because of less structured pedagogy, employment preparation is of concern as more structure is considered to stifle innovation in the workplace (Kelly et al. 2006; Shane 1995).

Lectures as a mode of structured instructional delivery were complemented, in this blended environment, with instructor facilitation of online group activities (Eom, Wen, and Ashill 2006). When the professor changes her or his role from the more traditional delivery of knowledge to become a student guide towards online material and facilitator in online group discussion and projects, it can increase uncertainty for students. The professor assigned team membership to introduce cultural diversity into online groups (Hornik and Tupchiy 2006; Hwang and Francesco 2010; Hwang, Kessler, and Francesco 2004). However, students expressed their uncertainty on this practice through less than positive survey comments. A preference was for certainty in the attitudes of familiar others, known performance, or regular decision making (House, Javidan, and Dorfman 2001). The author subsequently allowed students to continue their normal practice of choosing group members for projects, which were attributed a higher percentage for assessment. However, for online discussions that carried less weight in the final grading criteria, the professor continued to assign student group members. This practice was aligned with skills needed for a global workplace, as team orientation is vital for the ability to work across boundaries, to influence people without formal authority and to lead teams composed of different cultures (DeRue and Wellman 2009).

Assignments were formulated to increase knowledge about local issues. Students in this region require exposure to management in the Arab world because many will be employed in the Middle East (Abderrahman and Storti 2011). Students were familiar with searching online through the Internet for sources to complete assignments. However, a pedagogical approach to improve research quality, through use of the virtual library, created uncertainty as extra time was needed to locate these sources. It was concluded in a study of UAE students, that they did not appreciate the differences "between what is offered by library e-services and web search engine", and therefore, "seamless linking of e-learning and e-library" becomes crucial (Taha 2007, p. 359). Further links to library sources were embedded in the LMS, and a research workshop was later introduced in an attempt to ameliorate UA when searching for quality regional and global sources.

A change in the exam norm caused students to exhibit uncertainty, as revealed in narrative relating to perceived unfairness and increased time on activity. Education for those with high UA must "encourage gradual acquisition of knowledge and skills practiced in a supportive environment, where mistakes are never fatal" (Pech 2009, p. 61). Progressive change is suggested to reduce UA, e.g. a change to exam format, from written to electronic, followed later with other changes to exam procedure. The results agree with findings that learners from high UA cultures spend more time completing online tasks and attribute results to circumstances rather than acknowledging self-control for learning (Adeoye and Wentling 2007; Sulimma 2005). The introduction of blended learning makes necessary a longer view of time for 


\section{J. Kemp}

knowledge acquisition, that is more fitting with learners from high UA cultures (Tang and Koveos 2008).

\section{Limitations and future research direction}

A limitation of article length only allowed analysis of one dimension, (UA), in a culture framework to be applied to this introduction of blended learning. A further limitation is that data collected were from learners who were also taught by the survey creator. There was potential bias in data interpretation by the teacher/creator/ collector. To ameliorate bias, a research colleague reviewed the results, and a future survey is planned to collect data from learners taught by others. Survey data collected in other courses, and interpreted through other cultural dimensions, will extend the value of a culture framework for blended learning.

\section{Conclusion}

The mid semester LCLC survey addressed the research question, i.e. what evidence is there of learner uncertainty or certainty on the introduction of blended learning? To investigate the introduction of blended learning, an analysis of the cultural dimension of UA was conducted. Interpretation of certainty with blended learning was found in: student skills with technology; student acknowledgement of course organisation; and student appreciation of online feedback. Uncertainty with the introduction of blended learning was found: when membership was assigned for group work, higher quality research methods were introduced; where course structure lacked detail, increased time was required for new and different activities. Findings increased the international researcher's ability to interpret collected data on learner experiences within a cultural dimension (Kets de Vries 2004). A culture framework also offers valuable insights for the educator to effectively introduce blended learning to international students (Hofstede 1983; Hofstede, Hofstede, and Minkov 2010; House 2004; House, Hanges, and Ruiz-Quintanilla 1999).

\section{References}

Abderrahman, H. \& Storti, G. (2011) 'Organizational training across cultures: variations in practices and attitudes', Journal of European Industrial Training, vol. 35, no. 1, pp. 45-70.

Adeoye, B. \& Wentling, R. M. (2007) 'The relationship between national culture and the usability of an E-learning system', International Journal on E-learning, vol. 6, no. 1, pp. 119-146.

Alebaikan, R. \& Troudi, S. (2011) 'Blended learning in Saudi universities: challenges and perspectives', Research in Learning Technology, [online] Available at: http://www. researchinlearningtechnology.net/index.php/rlt/article/view/10750/12370

Alodiedat, A. \& Eyadat, Y. (2008) 'The effect of intranet use on students' achievement and self-confidence', International Management Review, vol. 4, no. 1, pp. 72-87, 109.

Bailey, J. (2006) 'From the editor: mission possible', Academy of Management Learning and Education, vol. 5, no. 1, pp. 5-7.

Bennett, S., Maton, K. \& Kervin, L. (2008) 'The "digital natives" debate: a critical review of the evidence', British Journal of Educational Technology, vol. 39, no. 5, pp. 775-786.

Benson, V., Anderson, D. \& Ooms, A. (2011) 'Educators' perceptions, attitudes and practices: blended learning in business and management education', Research in Learning Technology, [online] Available at: http://www.researchinlearningtechnology.net/index.php/rlt/article/view/ $10353 / 11979$ 
Deepwell, F. \& Malik, S. (2008) 'On campus, but out of class: an investigation into students' experiences of learning technologies in their self-directed study', Research in Learning Technology, [online] Available at: http://www.researchinlearningtechnology.net/index.php/ rlt/article/view/10881

DeRue, D. S. \& Wellman, N. (2009) 'Developing leaders via experience: the role of developmental challenge, learning orientation, and feedback availability', Journal of Applied Psychology, vol. 94, no. 4, pp. 859-875.

Dobbins, K. W. (2005) 'Getting ready for the net generation learner', Educause Review, vol. 40, no. 5 , pp. $8-9$.

Eom, S. B., Wen, H. \& Ashill, N. (2006) 'The determinants of students' perceived learning outcomes and satisfaction in University online education: an empirical investigation', Decision Sciences Journal of Innovative Education, vol. 4, no. 2, pp. 215-235.

Feiertag, J. \& Berge, Z. L. (2008) 'Training Generation N: how educators should approach the Net Generation', Education \& Training, vol. 50, no. 6, pp. 457-464.

Geçer, A. \& Dag, F. (2012) 'A blended learning experience', Educational Sciences: Theory \& Practice, vol. 12 , no. 1 , pp. 438-442.

Hofstede, G. (1980) Culture's Consequences: International Differences in Work-Related Values, Sage, London.

Hofstede, G. (1983) 'The cultural relativity of organizational practices and theories', Journal of International Business Studies, vol. 14, no. 2, pp. 75-89.

Hofstede, G. (2006) 'What did GLOBE really measure? Researchers' minds versus respondents' minds', Journal of International Business Studies, vol. 37, no. 6, pp. 882-896.

Hofstede, G. \& Hofstede, G. J. (2010) Cultures and Organizations: Software for the Mind, 3rd edn. [online] Available at: http://lib.myilibrary.com.ezproxy.aus.edu?ID=296125 15 April 2013.

Hornik, S. \& Tupchiy, A. (2006) 'Culture's impact on technology mediated learning: the role of horizontal and vertical individualism and collectivism', Journal of Global Information Management, vol. 14, no. 4, pp. 31-43, 45-56.

House, R. (2004) 'Culture, leadership and organizations, the GLOBE study of 62 societies', in Cultural Influences on Leadership and Organization Project GLOBE, eds R. J. House, P. J. Hanges, S. A. Ruiz-Quintanilla, P. W. Dorfman, et al., [online] Available at: http:// www.globalmindset.net

House, R., Javidan, M. \& Dorfman, P. (2001) 'Project GLOBE: an introduction', Applied Psychology: An International Review, vol. 50, no. 4, pp. 489-505.

House, R. J., Hanges, P. J. \& Ruiz-Quintanilla, S. A. (1999) 'Cultural influences on leadership and organizations: project GLOBE', Advances in Global Leadership, vol. 1, pp. $171-233$.

Hwang, A. \& Francesco, A. (2010) 'The influence of individualism- collectivism and power distance on use of feedback channels and consequences for learning', Academy of Management Learning and Education, vol. 9, no. 2, pp. 243-257.

Hwang, A., Kessler, E. \& Francesco, A. (2004) 'Student networking behavior, culture, and grade performance: an empirical study and pedagogical recommendations', Academy of Management Learning and Education, vol. 3, no. 2, pp. 139-150.

Internet World Stats. (2010) 'Usage and population statistics', Middle East, [online] Available at: http://www.internetworldstats.com/middle.htm\#ae

Javidan, M. \& House, R. (Guest eds) (2002) 'Leadership and cultures around the world: findings from GLOBE: an introduction to the special issue', Journal of World Business, vol. 37 , no. 1 , pp. $1-4$.

Javidan, M., et al. (2006) 'In the eye of the beholder: cross cultural lessons in leadership from project GLOBE', Academy of Management Perspectives, vol. 20, no. 1, pp. 67-90.

Kabasakal, H. \& Bodur, M. (2002) 'Arabic cluster: a bridge between East and West', Journal of World Business, vol. 37, no. 1, pp. 40-54.

Kabasakal, H. \& Dastmalchian, A. (2001) 'Introduction to the special issue on leadership and culture in the Middle East', Applied Psychology: An International Review, vol. 50, no. 4, pp. 479-488.

Kelly, S., et al. (2006) 'Leadership refrains: patterns of leadership', Leadership, vol. 2, no. 2, pp. 181-201. 


\section{J. Kemp}

Kemp, L. J. (2010) 'Teaching and learning for international students in a 'learning community'; creating, sharing and building knowledge', Insight: A Journal of Scholarly Teaching, vol. 5, pp. 59-70.

Kemp, L. J. (2011) 'A community of learning in multicultural management education; collaboration in virtual space', in Education in a Technological World: Communicating Current and Emerging Research and Technological Efforts, ed. A. Mendez-Vilas, Formatex Research Center, Spain.

Kets de Vries, M. (2004) 'Spotlight: cultural approaches to management', Management Decision, vol. 42, no. 7/8, pp. 925-931.

Lansari, A., Tubaishat, A. \& Al-Rawi, A. (2010) 'Using a learning management system to foster independent learning in an outcome-based university: a Gulf perspective', Issues in Informing Science \& Information Technology, vol. 7, pp. 73-87.

Martins, L. L. \& Kellermann, F. (2004) 'A model of business school students' acceptance of a web based course management system', Academy of Management Learning and Education, vol. 3, no. 1, pp. 7-26.

Maxwell, G., et al. (2000) 'Cultural diversity in learning: developing effective learning for South East Asian hospitality management students', Cross-Cultural Management, vol. 7, no. 3, pp. 3-12.

Mezias, S. (2009) Fulfilling the Vision for Knowledge-Driven Growth in the UAE, INSEAD Knowledge. INSEAD, [online] Available at: http://knowledge.insead.edu/world/middleeast/fulfilling-the-vision-for-knowledge-driven-growth-in-the-uae-1281

Miles, M. B. \& Huberman, A. M. (2002) 'Reflections and advice', in The Qualitative Researcher's Companion, eds M. B. Miles \& A. M. Huberman, Sage, London, pp. 393-397.

Miles, M. B. \& Huberman, M. (2004) Qualitative Data Analysis, 2nd ed, Sage, London.

Monitor. (2010) 'The net generation, unplugged technology and society: is it really helpful to talk about a new generation of "digital natives" who have grown up with the internet?' The Economist, [online] Available at: http://www.economist.com/node/15582279?story_id= 15582279

Motteram, G. \& Sharma, P. (2009) 'Blending learning in a web 2.0 world', International Journal Of Emerging Technologies and Society, vol. 7, no. 2, pp. 83-96.

Oblinger, D. G. \& Oblinger, J. L. (2005) 'Is it age or IT: first steps toward understanding the net generation', in Educating the Net Generation. Online: Educause, eds D. G. Oblinger \& J. L. Oblinger, [online] Available at: http://net.educause.edu/ir/library/pdf/pub7101.pdf

Owens, J. D. \& Price, L. (2010) 'Is e-learning replacing the traditional lecture?', Education+ Training, vol. 52, no. 2, pp. 128-139.

Pech, R. (2009) 'Emiratization: aligning education with future needs in the United Arab Emirates', Education, Business and Society: Contemporary Middle Eastern Issues, vol. 2, no. 1 , pp. $57-65$.

Postman, N. (1992) Technopoly: The Surrender of Culture to Technology, Vintage Books, New York.

Prensky, M. (2001) 'Digital natives, digital immigrants', On the Horizon, vol. 9, no. 5, pp. 1-6. MCB University Press.

Project GLOBE. (2010) 'History', Thunderbird School of Global Management, [online] Available at: http://www.thunderbird.edu/sites/globe/history/index.htm

Proserpio, L. \& Gioia, D. A. (2007) 'Teaching the virtual generation', Academy of Management Learning and Education, vol. 6, no. 1, pp. 69-80.

Rodrigues, C. A. (2005) 'Culture as a determinant of the importance level business students place on ten teaching/learning techniques: a survey of university students', The Journal of Management Development, vol. 24, no. 7/8, pp. 608-621.

Ronen, S. \& Shenkar, O. (1985) 'Clustering countries on attitudinal dimensions: a review and synthesis', Academy of Management Review, vol. 10, no. 3, pp. 435-454.

Selvarajah, C. (2006) 'Cross-cultural study of Asian and European student perception: the need to understand the changing educational environment in New Zealand', CrossCultural Management, vol. 13, pp. 142-155.

Shane, S. (1995) 'Uncertainty avoidance and the preference for innovation championing roles', Journal of International Business Studies, vol. 26, no. 1, pp. 47-68.

Sulimma, M. (2005) 'Relations between epistemological beliefs and culture classifications', Multicultural Education and Technology Journal, vol. 3, no. 1, pp. 74-89. 
Sulkowski, N. \& Deakin, M. K. (2010) 'Implications of internationalisation on learning and teaching - listening to the winds of change?', Journal of Hospitality, Leisure, Sports and Tourism Education, vol. 9, no. 1, pp. 110-116.

Taha, A. (2007) 'Networked e-information services to support the e-learning process at UAE university', The Electronic Library, vol. 25, no. 3, pp. 349-362.

Tang, L. \& Koveos, P. (2008) 'A framework to update Hofstede's cultural value indices: economic dynamics and institutional stability', Journal of International Business Studies, vol. 39, no. 6, pp. 1045-1063.

The Hofstede Centre. (2012) 'What about the Arab world', UA, and the 'Arab Emirates', [online] Available at: http://geert-hofstede.com/arab-world-egiqkwlblysa.html and http:// geert-hofstede.com/arab-emirates.html

UAE Statistics Bureau. (2011) 'Demographics', [online] Available at: http://www.uaestatistics. gov.ae/EnglishHome/tabid/96/Default.aspx

Venaik, S. \& Brewer, P. (2010) 'Avoiding uncertainty in Hofstede and GLOBE', Journal of International Business Studies, vol. 41, no. 8, pp. 1294-1315.

World Bank. (2008) 'New challenges facing the education sector in MENA, the road not traveled', Education reform in the Middle East and North Africa, MENA development report, [online] pp. 83-114. Available at: siteresources.worldbank.org/.../EDU_Flagship_ Full_ENG.pdf 